\title{
Analysis of mathematical models of drilling describing surface quality and tool overload protection aspects
}

\author{
Dilyaver Abdulgazis ${ }^{1}$, Ervin Umerov ${ }^{1, *}$, and Umer Abdulgazis ${ }^{1}$ \\ ${ }^{1}$ Crimean Engineering and Pedagogical University, Lane training, 8, Simferopol, 295015, \\ Simferopol, Republic of Crimea, Russian Federation
}

\begin{abstract}
In the article, taking into account the specifics of the drilling operation, especially deep, the analysis of the known mathematical models describing the aspects of ensuring the accuracy and quality of the holes is presented. Based on the results of the analysis of the known mathematical models, it is concluded that the available dependences cover only part of the problem of improving the accuracy, aging the shape of the hole and the quality of its surface. The expediency of development of mathematical models more widely covering technological systems of drilling of holes, especially in difficult materials is shown. An example of the work of the system of stabilization of the load on the drill, where the correction of adjustable values is carried out by the current drilling depth.
\end{abstract}

\section{Formulation of the problem}

Increase of the processing accuracy and reliability of the deep drilling process is achieved by creating and using precise mathematical models of the drilling process, taking into account the specifics of the phenomena occurring in the processing zone and elastic deformations of the technological system.

The specifics of drilling operations, especially deep drilling, is that the tool makes its way in a solid material, without having a rigid direction. The process is further aggravated by the heterogeneous quality of the processed material. In addition, chip formation takes place under conditions of complicated chip removal.

The greater the depth of drilling, the heavier the working condition of the drill. This is further aggravated by the specifics of supplying fresh lube coolant to the cutting zone during drilling, and also greater contact time between the chip, the tool and the workpiece being processed than during the machining, and as a consequence, a significant temperature increase in the cutting area. With increasing depth of processing, the chips are accumulated in the chip stripping ducts, which contributes to the growth of the process power parameters.

Vibration of the tool leads to the formation of the cut of the hole, and the specific nature of the wear of the guide drills causes the formation of a taper and an increased surface

\footnotetext{
*Corresponding author: ervin777@yandex.ru
} 
roughness. Scratches on the walls of the resulting hole are usually due to the accumulation and packing of chips in the chipping channels of the drill. Dyeing of cutting edges and guides, jamming of chip particles between the formed hole and the drill guides create burrs on the surface of hole formation.

Production and research experience shows that despite a large number of designs on optimization of cutting conditions, improvement of the tool and lube coolant, it is not possible to eliminate the increase in the power load on the drill during its penetration.

The foregoing indicates the advisability of creating control systems for the drilling process in order to improve the quality of hole machining and increase the durability of the core tool.

The article objective is to analyze mathematical models of the technological process of hole drilling in order to improve the methods of protecting the core tool from overload and improve the processing quality management.

\section{The main part}

The solution of the objective to improve the processing quality and protect the tool against overloading with the aim of increasing its durability can be achieved by using methods of process characteristics of machines, tools and supplied lube coolant improvement, as well as controlling the cutting modes.

The main effect on the accuracy of the diametrical size, the geometric shape of the hole in the longitudinal and transverse directions, the accuracy of the hole axis direction and the roughness parameters of the resulting surfaces during drilling are due to:

- significant adhesion between the tool and the chips;

- uneven hardness of the workpiece material;

- asymmetrical wear of the drill bits;

- asymmetry of sharpening of drill blades.

A large drill outreach in combination with its small diameter promotes the appearance of radial components of cutting forces.

Let's analyze the mathematical models of the drilling process that describe various aspects of ensuring the hole quality.

In the paper [1], a computational and analytical method for determining the error acquired by a part as a result of processing is proposed. The essence of the method is to determine and summarize the individual components of the error. It takes into account the following systematic errors: geometric inaccuracy of the machine $\left(\Delta_{1}\right)$; wear of the cutting tool $\left(\Delta_{2}\right)$; thermal deformation of the technological system $\left(\Delta_{3}\right)$; elastic deformation of the technological system $\left(\Delta_{4}\right)$; inaccuracy of the machine setting $\left(\Delta_{5}\right)$; random errors, which depend on the uneven hardness of the workpiece being processed $\left(\Delta \operatorname{ran}_{1}\right)$; measurement error $\left(\Delta \mathrm{sl}_{2}\right)$.

Thus, the total error can be represented as:

$$
\Delta \text { total }=\Delta_{1}+\Delta_{2}+\Delta_{3}+\Delta_{4}+\Delta_{5}+\Delta \operatorname{ran}_{1}+\Delta \operatorname{ran}_{2}
$$

In a single and small-scale production, only systematic errors are necessarily taken into account.

Formula (1) determines the error in the size of the processed surface, and in order to evaluate the error of the geometric shape it is necessary to determine the difference in the resulting corresponding dimensions of the part with the dimensions of the drawing.

In formula (1), the elastic deformations caused by the non-rigidity of the tool (in our case this drill being the least rigid of the entire list of the blade tools) are included in the component $\Delta 4$, which takes into account the elastic deformations of the technological 
system.

In the paper [2], the effect of the radial component of the cutting force on the elastic tool line is represented by the formula

$$
y=\frac{F_{p}}{3 E J}(x-l)^{3},
$$

where $F_{\mathrm{p}}$ is the value of the radial force acting on the drill bit;

$E$ is modulus of elasticity of the drill material;

$J$ is the moment of inertia of the cross section of the drill;

$x$ is the coordinate of the cross section;

$l$ is the length of the working part of the drill bit.

The initial displacement of the drill axis in the same paper [2] is proposed to be determined from the formula

$$
e=\frac{F_{p} l^{3}}{3 E J},
$$

and the magnitude of the angle of inclination of the axis at its vertex from the formula

$$
\varphi_{l}=\frac{F_{p} l^{2}}{2 E J},
$$

The drill run-out value by the completion of the drilling process is suggested [2] to be defined as

$$
y_{\mathrm{K}}=\left(e_{\mathrm{y}}+e\right)+\left(\operatorname{tg} \alpha_{\mathrm{y}}+\operatorname{tg} \varphi\right) \cdot L
$$

where $e_{y}$ is the amount of drill displacement from the center of the workpiece;

$\alpha_{y}$ is the angular error due to incorrect setting of the workpiece base relative to the axis of the machine spindle.

It is considered [2] that the errors $e_{y}$ and $\alpha_{y}$ are relatively small and can be eliminated in the adjustment process.

The second and fourth terms of the formula (5) respectively show the initial displacement (1) and the angular error of the hole axis when the drill is inserted.

In the paper [3], based on the results of extensive analysis of the causes of drift during deep drilling, the magnitude of the axis drift in any cross-section as a result of the heterogeneity of the billet material was proposed to be determined from the dependence

$$
Y_{c i}=\sqrt{y_{i}^{2}-z_{i}^{2}}
$$

where $y_{i}$ and $z_{i}$ are the drift components determined by the dependences

$$
\begin{aligned}
& y=y_{0}+l_{c} \operatorname{tg} \alpha_{y}+\int_{0}^{l} B_{y} d x, \\
& z=z_{0}+l_{c} \operatorname{tg} \alpha_{z}+\int_{0}^{l} B_{z} d z .
\end{aligned}
$$

In dependences (7) and (8) it is customary to: 
$y_{0}$ and $z_{0}$ are the coordinates of the tool's entry into the workpiece;

$\alpha_{y}$ and $\alpha_{z}$ are the angular errors when the tool is inserted into the workpiece;

$B_{y}$ and $B_{z}$ are dimensionless functions that determine the transverse deviations of the drill under the influence of the hardness variations in the workpiece material.

These models do not take into account the elastic properties of the technological system, which have a significant effect on the accuracy of processing and power parameters.

In the paper [4], the task of controlling the machine system when drilling deep holes was set in order to optimize depressions. The machine system model is represented as follows.

$$
\frac{d x}{d t}=a \vec{x}+b \vec{f}+c \vec{u}
$$

where $\vec{x}(t)=\left\{x_{1}(t), x_{2}(t), \ldots x_{n}(t)\right\}^{T}$ is the state vector of the controlled system;

$f$ is the vector of external disturbances;

$u$ is the control vector;

$a, b, c$ are matrices of constant factors.

A number of studies [5-8] are aimed at establishing the causes of the sourcing and development of oscillations of a relatively small amplitude accompanying the cutting processes. The nature of the oscillations during machining with the shank tool is considered to be dependent on the number and location of the cutting edges, the length of the tool, the shape of its cross section, the cutting mode, the composition of the supplied lube coolants, the uniformity of the material being processed.

In the paper [8] the mathematical model of the oscillatory system is considered as a differential equation:

$$
M \ddot{x}=j x+F_{f}
$$

where $M$ is the reduced mass of the system;

$j$ is the system stiffness;

$F_{f}$ is the feed force.

Considering equation (10) with respect to drilling, it can be stated that it does not take into account the possible radial forces that are unavoidable for this process. The latter is said to significantly determine the accuracy of processing and the surfaces quality of the holes obtained. In the paper [2], the excess unbalanced radial component is estimated as having a dominant effect on the geometric shape of the hole being made.

The differential equation of motion under the action of the elastic reaction of the tool in [8] is presented in the form:

$$
m \ddot{y}+c \dot{y}+F=F_{p},
$$

where $F$ is the elastic response of the tool;

$m$ is the reduced mass;

$F_{p}$ is the radial force projection;

$c$ is the damping factor.

Mathematical models of the accumulated drifts of spiral drills along the hole length in [9] are presented in the form 


$$
\begin{aligned}
& y(x)=\left(x / x_{0}\right)^{1,5} \\
& z(x)=\frac{q}{120 E J} x^{4}+\left(z_{0} x_{0}^{-1,5}-\frac{q}{120 E J} x^{2,5}\right) x^{1,5}
\end{aligned}
$$

where $x$ is the drill out of the chuck;

$y(x), z(x)$ are the projections of the displacement vector $r(x)$ on the horizontal and vertical planes;

$z_{0}$ is the linear errors in the initial direction of the drill in the vertical plane;

$x_{0}$ is the distance from the point where the drill is fastened to the workpiece;

$q$ is the distributed load from the mass of the drill;

$S$ is the cross-sectional area of the drill;

$E J$ is the bending rigidity of the drill.

Next, we consider the available design developments to protect the core tool (drills) from overloads, in order to increase its resistance.

The main force parameters of the drilling process, which determine the working conditions of the tool, are the axial force and the torque applied to the drill.

The restriction on the drill strength according to $[9,10]$, we express as

$$
\sigma_{\mathrm{eq}}<[\sigma]
$$

provided that

$$
\sigma_{\mathrm{eq}}<a\left(c \mathrm{M}-F_{f}\right),
$$

where $\sigma_{e q}$ is the maximum value of the equivalent stress arising from the combined action of the axial force and the torque applied to the drill;

$[\sigma]$ - the limiting value of the destructive stress;

$a$ and $c$ are the factors selected depending on the drill material used;

$\mathrm{F}_{\mathrm{f}}$ is the axial component of the cutting force;

The constraint on strength can be expressed more simply

$$
M<[M] .
$$

While a certain depth is reached, the restriction of the axial force loses significant significance. The torque is becoming dominant, and it is necessary to stabilize it with the help of the drilling process control system.

A number of studies [9-11] showed that the torque restriction is especially important at the initial stage of the drilling operation, when the free part of the drill bit is still large enough. Fulfillment of such a restriction at the initial stage does not allow the development of an incorrigible drift of the drill.

In [12] an option of the automatic control system (ACS) containing two circuits is proposed: axial force control and torque control. Correction of the adjustable values is carried out in the proposed system according to the current drilling depth. The figure shows the scheme of this system as in [13]. 


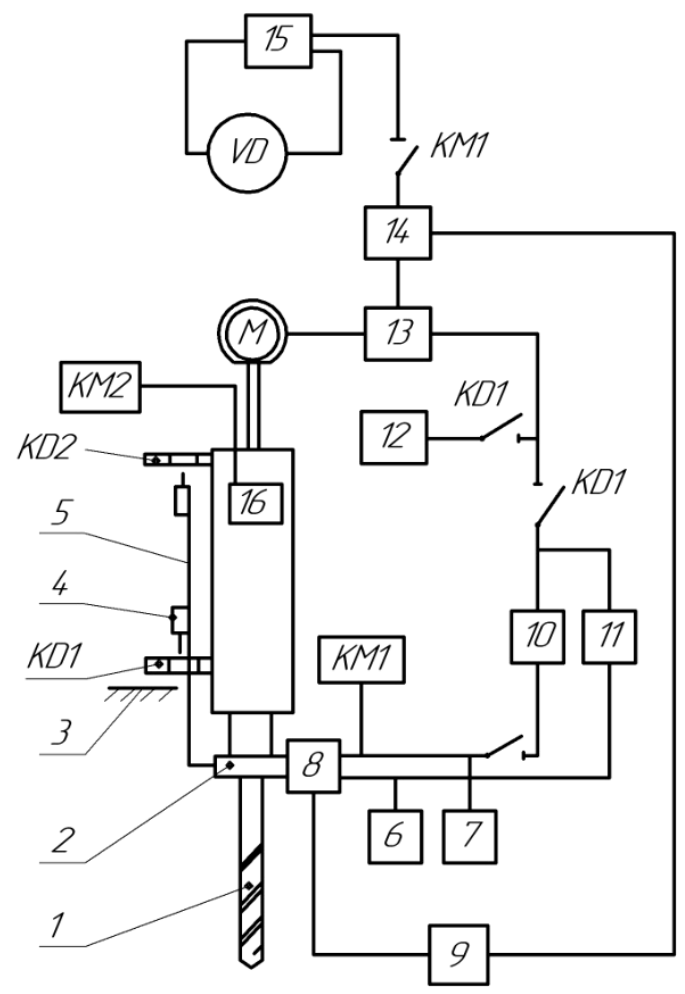

Fig. 1. The diagram of the drill load stabilization system [13]:

1- drill; 2 - chuck; 3 - retainer; 4 - movable shutter; 5 - guide; 6 and 7 - axial force and torque sensors; 8 - axial force and torque measurement unit; 9 - threshold element; 10 and 11 - regulators; 12 - quick-approach and reverse speed sensor; 13 - drive control system; 14 - logic block; 15 threshold element; 16 - movement sensor.

The tool before the drill is in contact with the workpiece is fed at a fast feed rate, its speed is determined by sensor 12. The movable shutter 4 fixed to the desired position overlaps the LED of the sensor KD1 and the shift to the working feed occurs.

In case of an unacceptable reduction in the speed of the drillaxial feed, the threshold element 15 is triggered, while at the output of the logic block 14 a signal is sent to the intermediate removal of the drill for cooling and forced chip removal.

The measuring unit 8 connected via the element 9 to the logic block 14 determines the maximum permissible torque applied to the drill. In case of sharp torque overloads of the drill, the element 14 sends a signal to its intermediate removal.

The movement sensor, as the depth of drilling increases, changes the signal strength, by the value of which the relay element KM2 reacts.

Estimating the value of the two power factors, starting from a certain depth of drilling, the switchover from the axial force control to the torque control occurs.

The shutter 4 moves in the process of retracting the drill bit at a quick feed (retraction) along with the guide 5 . When the cutting edges of the drill come out of the hole, the KD2 sensor is triggered, the tool's reverse is stopped and the drill returns to the end point of the previous drilling by fast feed. Before the drill strarts cutting, the transmission of the machine is switched to the speed of the working feed.

Structural diagrams of devices for protecting drills from overloads are many, for example, author's certificates [14-19]. 


\section{Conclusions}

1. The above analysis of known mathematical models shows that the available dependencies cover only part of the problem of increasing accuracy, keeping the shape of the hole and the quality of its surface. It is advisable to develop mathematical models that more broadly cover the technological systems of holes drilling, especially in hard-to-cut materials, taking into account the characteristics of the supply of coolant-lubricants and their composition.

2. There is a number of methods to stabilize the load on a drill with high speed determining the mode of tool overload and allowing for feed control.

\section{References}

1. Sokolovskij A.P. Raschety tochnosti obrabotki na metallorezhushchih stankah (Moscow: Mashgiz, 1952).

2. Holmogorcev YU.P. Optimizaciya processov obrabotki otverstij (Moscow: Mashinostroenie, 1984)

3. Troickij N.D. Glubokoe sverlenie (Leningrad: Mashinostroenie, 1982)

4. N.F. Utkin, YU.I. Kizhnyaev, S.K. Pluzhnikov, A.A. Shamanin, F.M. Drozdov, Obrabotka glubokih otverstij (Leningrad: mashinostroenie, 1988)

5. Zhitomirskij V.K. Mekhanicheskie kolebaniya I praktika ih ustraneniya (Moscow: Mashisnotroenie, 1966)

6. Kedrov S.S. Kolebaniya metallorezhushchih stankov (Moscow: Mashinostroenie, 1978)

7. Kumabe D. Vibracionnoe rezanie (Moscow: Mashinostroenie, 1985)

8. L.S. Murashkin, S.L. Murashkin Prikladnaya nelinejnaya mekhanika stankov (Leningrad: Mashinostroenie, 1977)

9. Nazarenko D.V. Optimizaciya processa sverleniya glubokih otverstij malogo diametra. Avtoref. diss. nasoik. kand.tekhn. nauk. Rostov-na-Donu: Donskojgosud. tekhn. Universitet, 1998, $18 \mathrm{p}$.

10. Tverskoj M.M. Avtomaticheskoe upravlenie rezhimami obrabotki detalej na stankah (Moscow: Mashinostroenie, 1982)

11. B.S. Balakshin, Samopodnastraivayushchiesya stanki (Moscow: Mashinostroenie, 1970)

12. Levchenko A.I. Sistema upravleniya parametrami nagruzki pri glubokom sverlenii, Materialy 3-j mezhdunarodnojnauchn.-tekhn. konf. «Avtomobil'nyj transport: progress, tekhnologii, kadry» - Sevastopol': Izd-voSevGTU, 1999, 202 p.

13. Levchenko A.I. Stabilizaciya silovyh peremennyh rezhima pri obrabotke otverstij, TOOLS 2000: Proc. of the Int. Conf. - Bratislava, 2000 - Pr. 176-178.

14. A.s. 1154062 A SSSR, MKI V 23 V 47/24. Ustrojstvo dlya zashchity sterzhnevogo instrumenta / Sharov E.T., Taranenko V.A., Kanareev F.N. - appl. 13.02.84; publ. 07.05.85, Byul. №17.

15. A.s. 1155421 A SSSR, MKI V 23 V 49/00. Sposob zashchity instrumenta ot peregruzokiustrojstvodlya ego realzacii / Sharov E.T., Taranenko V.A. - appl. 13.01.84; publ. 15.05.85, Byul. №18.

16. A.s. 1255299 A SSSR, MKI V 23 V 49/00. Ustrojstvo dlya kontrolyapolozheniya instrumenta / Sharov E.T., Taranenko V.A., Kanareev F.N. - appl. 16.04.85; publ. 
07.09.86, Byul. №33.

17. A.s. 1269973 A1 SSSR, MKI V 23 Q 15/00. Ustrojstvo dlya zashchity instrumenta / Sharov E.T., Taranenko V.A. - appl. 26.04.84; publ. 15.11.86, Byul. №42.

18. A.s. 1271676 A1 SSSR, MKI V 23 V 49/00. Ustrojstvo dlya zashchity koncevogo instrumenta / Sharov E.T., Taranenko V.A. - appl. 05.05.85; publ. 23.11.86, Byul. №43.

19. A.s. 1414523 A1 SSSR, MKI V 23 V 49/00. Ustrojstvo dlya kontrolya peregruzki $i$ polomki sterzhnevogo instrumenta / Sharov E.T., Taranenko V.A., Strashko V.N. appl. 19.01.87; publ. 07.08.88, Byul. №29. 